\title{
A MAGAZINE PUBLISHER'S LOT \\ IS NOT A HAPPY ONE
}

\author{
BY TODD HUNT
}

Mr. Hunt is an assistant professor in the Rutgers School of Journalism.

$\mathrm{H}$

OW churlish can you get? Publishers of the new Scanlan's monthly magazine have announced they will charge letterwriters 25 cents a word. What's more: "Letters which we find particularly dumb or boring will cost $\$$ I.oo per word, and they will only be put into type after the writer's check clears the bank."

Unprecedented and shameful? Not really.

The publisher's lot-like that of Gilbert and Sullivan's policeman-is not a happy one. It's been that way since the earliest days of American magazines, if we are to judge from the pleas, admonitions and reprimands directed at generations of numskull readers.

Colonial printers were hard-pressed to build the circulation of their journals. Besides the short supply of paper, there was the difficulty of convincing subscribers to pay up. Faced with a cash shortage in I 779, New Jersey printer Isaac Collins admitted in his Gazette that he was forced "to fall upon some plan for fixing the Value of Subscriptions." In place of money, the publisher agreed to accept grain, wool or dairy products in payment.

In the early I80os, periodicals were sent through the postal service at no cost to the publisher-the subscriber paid the charges upon receiving the item. That practice inevitably resulted in lost and strayed magazines, and in I 8 I 8 the printer-publisher of Baltimore's Niles' Weekly Register used the classic pointing-hand typographical device to call attention to this announcement:

The editor of the WEEKLY REGISTER gratefully acknowledges occasional notices from postmasters of some of his papers not being taken out of their offices, in consequence of the decease or removal of persons to whom they were addressed ... While on the subject, may we express our astonishment at the late uncommonly frequent interceptions, or interruptions of the REGISTER, when passing to those for whom it is destined; and will sincerely thank any one that can give us a clue to discover its cause.

It wasn't until I 875 that the postal service required periodicals to be mailed with postage prepaid. By that time it was common prac- 
tice to offer subscriptions at cut rates if the readers grouped together in clubs for ordering purposes. Handsome premiums were offered as well-dress patterns, reprints, extra issues, or engravings suitable for framing. The popular Peterson's Ladies National Magazine offered an artistic representation of "Washington's First Interview With His Wife" as a come-on, and apprised the readership in its Prospectus: "The postage for the year, remember, is included in the prices ... Persons getting up clubs should be particular to explain this to subscribers."

Prodding the public into renewing has always been a ritual guaranteed to try a publisher's patience. As gentle and polite a plea ever entered in that regard was to be found in Harper's New Monthly Magazine at the conclusion of Volume 63 in November, I 881 :

Those desiring to renew their subscriptions to HARPER'S PERIODICALS will much oblige the publishers by sending in their names as early as convenient before the expiration of their present subscriptions. This will obviate the delay attendant upon re-entering names and mailing back numbers.

However, reviewing the year and forecasting the next, the publishers proved somewhat less unassuming:

In its illustrations, HARPER'S MAGAZINE takes a conspicuous position. In this department, as in that of literature, its progress has been a steady though rapid development, carefully avoiding sensational novelty and eccentricity. The average cost of the illustrations for each Number is over five thousand dollars!

Convincing the audience of a magazine's merits was hardly the only concern facing publishers. At times the readers had to be given the most basic education in how to use the product. In response to piteous letters from subscribers who had marred their precious Numbers attempting to remove the wrappers, the December, I 889, issue of Ingalls' Home Magazine carried special directions:

To take the wrapper off without tearing the Magazine, run a knife the entire length of the wrapper, bearing on hard enough to cut through, but not into the Magazine; roll in the opposite direction to what it was rolled, and it will lay flat.

Similar replies to simplistic requests filled the same magazine's Correspondence department. Some readers were nearly hysterical 
to have missed certain Numbers containing serialized stories and promised features. As a consequence, the publishers had to carry back numbers in stock and reassure readers that all orders would be filled.

Readers at the turn of the century needed constant reassurance concerning the reputations of the publications that filled their mailboxes. The editors of the staid, upright and typographically backwards Farm Journal of I 902 led off column one, page one of each issue with the assurance that "The FARM JOURNAL gives no chromos, puffs no swindles, inserts no humbug advertisements, and does not devote one-half of its space to telling how good the other half is."

The Editors of Gas Review, issued from Madison, Wisconsin, for the benefit of gasoline and oil engine users, advised: "We guarantee every subscriber against loss through dishonesty or attempted swindle by any advertiser in this publication. We do not attempt, however, to adjust trifling differences between the subscribers and honest, responsible advertisers, nor will we pay the debts of honest bankrupts."

By the beginning of World War I, magazine subscription deceptions so plagued publishers that the popular magazines carried dire warnings:

IMPORTANT NOTICE: Do not subscribe to THE BLUE BOOK MAGAZINE through agents unknown to you personally, or you may find yourself defrauded. Many complaints are received from people who have paid cash to some swindler, in which event, of course, the subscription never reaches this office.

Free-lance contributors have always been the leading cause of headaches for editors and publishers. But the impersonal rejection slip is a relatively new development. In the I $9^{\text {th }}$ century, freelancers used pen names and slipped their work under the door, so the editors were compelled to announce acceptances and rejections in the pages of their publication. The Nerw-York Mirror of I 83940, a weekly review of literature and the arts, included these stinging barbs in a column addressed "TO READERS AND CORRESPONDENTS":

The fair correspondent to whom we are indebted for the "Letters on the Northern Mythology" is requested to render the chirography of her communications a little more legible. 
The basket of poetry sent in by "Qy" lies at our office, subject to the disposal of the author. If he do not call for it soon, we cannot ensure its safety, as we have strong suspicions that our office-boys intend to use it, some cold morning, for kindling our anthracite.

And the same column for February 8, I 840 carries this testy admonition aimed at other publishers: "On the last page is an original, and what is better, a beautiful composition, creditable to the Genius of Mr. Maeder, whom we thank for communicating it to the Mirror. Those who pirate it will please to say from what journal it is taken."

The patience of peppery H. L. Mencken was often sorely tried by would-be contributors. In his "Editorial Notes" column for the November, 1926, issue he vented his wrath:

The American Mercury is especially eager to print the works of new writers. A great deal of it comes in, and all of it is read with care, and by experts of long experience and great gifts. But they report that they find only bilge. All the newcomers write alike, and in the manner of the hacks who supply the cheap magazines. Every story is well-made, and every one is as hollow as a jug. Such are the effects of pedagogy when it is applied to one of the fine arts. The teachers of short-story writing seem to be unanimously distinguished by their ignorance of the thing they presume to teach . . . But their flaming advertisements fetch the young aspirants, and the result is sadness in all the editorial offices of the United States.

Vexed by subscribers who complained of non-receipt by writing to the editors, or even to the wrong magazine, Mencken offered yet another lament:

It may seem incredible, but it is a solemn fact that an appreciable number of friends of the magazine seem to believe that it is published in Boston. The Postoffice is extraordinarily intelligent and competent in such matters: letters so misaddressed are forwarded to New York at once. But it takes time. And it takes time, too, to recover letters addressed to Baltimore. Much mail is sent to the editor there. Sometimes it lies in his barn for a week. . .

When The Atlantic Monthly, in the early issues of 1929, ran a series called "Lincoln the Lover," purporting to be epistles d'amour between the president and various ladies, the readers were irate, and many claimed the letters were fraudulent. Miffed, the editors replied:

For the criticism of scholars and students, no matter how unfavorable, 
we are not ungrateful, for the truth in this matter is of deep interest. We do feel that multifarious criticism by persons quite ignorant of the merits of the controversy proves once again how inequitable sense and intelligence are distributed in this world.

Readers stung by that denunciation from on high were happy to see the publisher receive his comeuppance soon after when the supposed love letters were debunked and admitted by the author to be counterfeit.

Perhaps these unceasing tales of publishing woe should be balanced with the turning of a few pages of what was surely the happiest periodical of the I850s, The American Cotton Planter and the Soil of the South, published in Montgomery, Ala. The ebullient "Editor and Proprietor," N. B. Cloud, summarized his joy in this lead-off item in the March, I858, issue:

The Magazine having atained (sic) an extent of circulation never heretofore accomplished by an Agricultural Periodical in the South and West, has therefore on account of the character of its readers and the style in which it is gotten up, become a favorite and most efficient medium for Advertising.

Elsewhere in the same issue, the generously rewarded Horticultural Editor C. A. Peabody was disposed to end his column with a cornucopia of acknowledgements:

We are under obligations to the Hon. C. C. Clay, for copies of the Agricultural Report of the Patent Office, also to the Hon. Robert Toombs, for valuable public documents. Also to Wm. G. Mood of Aiken, South Carolina, for a package of seeds. Also to the Hon. Mansel White of New Orleans, for a cask of syrup, the pure juice of cane, and a box of wine made from the sugar cane, both of which are extra fine. Also to Messrs. Peter \& Harden, of Atlanta, Georgia, for a package of choice roses and native mountain Azelios (sic), all of which shall grace our grounds around the homestead.

Gifts of wine and roses aren't typical, nor quite ethical, today. But they would doubtless make a publisher's lot a happy one. 


\section{NILES' WEEKLY REGISTER.}

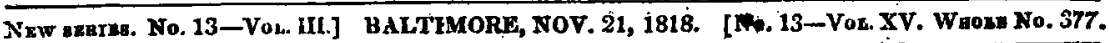

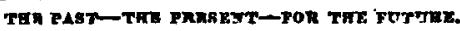

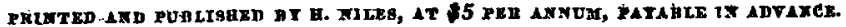

Inponten ouóns. It was only a few days since, though we had industriously sought for it, that we could obtain the last official account published of the "importations of the United States"-which is, for the year ending Sept. 30, 1816; and consider. ing it, in many respects, as a very inportant document, we have hastened to present its aggregate statement," as being amply sufficient all for ordinary purposes. To this, by the generous aid of a mer. cantile friend, we have the pleasure to add a very interesting estimate of the vulue of the artieles imported (not given in the of sether with a summary statement of their actual cost to the people of the United States. We venture to say that this estimate and summary are as nearly correct as they can be-for the gentleman did not depend only, upon his own clear recollecthons of facts, but also referred to many pricescurrent of the year before.he put down the average value of any article given. We therefore, assume the whole as dota that may be relied upon,-Oa this important subject, an essay of considerable Hength is prepared for the press, but which of neces. sity, with a great quantity of other matter, is postponed till next week-when zoe shall publish a supplementary sheet to keep pace with the multiplication of our materials. We have yet much to say on banking-which, we learn from many quarters, is committing dreadful ravages on the people; But there is good resson to believe that caution is beginning to be esteemed as the parent of security.

Extract of a letter from a gentleman who had remit. ted to the editor a bitt of the "Indefendent munty facturing canpany of Bultimor $e^{. "}$

"I am exceedingly sorry that I happened to remit to.you a note of "no value." It had all the exteriors of genuineness about it-"fine rags," a pretty picuire, the usual guantity of officers who could write heir names in a passable hand-with "chartered Dy the siaté of Maryland," proudly displayed on a flag-staff. In a word, as much of a specie-paying appearunce as any of its kindred, and would be as likely to pass through the world as creditably as any rag amongst them, but for such ill-fated wight a yourgelf, who have crouked evil of them for the Inst twelve months. I wonder that they have not an instinctive dreud of you!"

[A vast number of counterfeit or fictitious notes are spread through the United States-they are chiefly circulated by traveluing merchants from the eastward, that irade in any ting; who-have been seen frequently in this city to barter their goods for paper having the appearance of bank-bills, but known to them to be of "no value;" and this kind of trafic constitutes a very profitable purt of their business. In times so prodigal of crime as to mo ney-making, as the present, the only safety of the people, who do not handle many bank-notes-is, peremptorily to refuse every one that they do not know to be geutuine, if offered by an irresponsibie prergòn.]

* Our tables-pressed inlo fuur pages, are a full and perfeot copy of the othcial agriegrate stutement, swich occupies fifty thee octoro fures!

var. $x$ V. . 1 .
Another lęter to the editor arys-

"This aection of the country has suffered much from banks - no less than four have existed in our ittle village of only about 4000 inhabitants-but we rejoice that the law has taken bold of one of them; another is. about to be withdrawn; and we therefore anticipate the happy period when we shall have only two more than we stand il need of?"

$\mathcal{A}$ member of congress, coriting to his friend in Bnhtmore, and referring to the editor of the Register, $8 \mathrm{chy} / \mathrm{s}-$

"Can you or he tell me how we are to reform the currency of the country, 1 mean the rag currency. I out-rode the credit of the paper I atarted with and had to turn oroker, and exchanged it with tra. veller's going westward-for paper on bants situated to the eastward, the credit of which they had also oui-rode."

The message of the president is $\AA$ very plain state paper-and every one will be able to under stand it-without comment. It leads us to expect many highly important documents, which shall be in. serted in the RRGIstur with all the possible despatch that can be attached to a zoeekly period of publication. And as those things are of the first interest to the people, they shall be preferred to every thing else, until they are disposed of:

CTo postmasters. The editor of the Whexry Registin gratefully scknowledges occasional notices from postmasters, of some of his papers not being taken ont of their offices; in consequence of the decease or removal of persons to whom they were atdressed. We again insert the directions of the postmaster gereral on this subject to remind any, if any there be, that it is as well an act of duty as of cotirtesy, to give editors of papers such infornation:

Gexmin gogt-orfics, rov. 16, 1816.

The several postmasteys are hereby required whenever a persón, to whom a newspuper is ad. dressed, ceases to take it out of the post-office, to advise the editor of the paper thereof; and to add, if known; whether the person is dead, moved away, or merely refuses. The mail is burthened with many newspapets, which are 2 loss to the proprie. tors, as well as the public.

f. J. MEIGS, jam. Host Master General.

WWhile on this subject we may express our astonishment at the late uncommonly frequent interceptions, or interruptions of the REGreTse, when passing to those for whom it is destined; and will sincerely thank any one that oan give us a clue to discover its cause. We have also to regret, that although our.paper is packed with ifs usteal carein a better manner, perhaps, than any other in the United States, that is latterly much damaged is the mail-several times even between Hallimore and New York. Having been generally, as well served in this important concern as we could have expected, we must confess we do not undersiand why so many just complaints should at this time exist: We are sure that the fault does nos ha in the post-office here: 